\title{
OFFICIAL OPENING OF THE BAR LIBRARY $21^{\text {st }}$ NOVEMBER 2003
}

Peter Cush, Chairman of the Executive and Bar Council, welcomed guests to the official opening of the Bar Library on $21^{\text {st }}$ November 2003. He paid tribute to the work of previous chairmen, namely, Richard McLaughlin, Eugene Grant, Brian Fee, the late John Cushinan, Eilis McDermott and Reg Weir for the energy and enthusiasm which they gave to this project. He also paid particular thanks to the Development Committee and its chairmen, John Gillen and Brian Fee, for their attention to detail as the project developed, and to the staff who achieved the major move to the new premises so efficiently.

The architects, Robinson McIlwaine, the builders, Gilbert-Ash and the furniture manufacturers, Calvert Morgan have provided the Bar with a building which is already recognised as having made a significant contribution to the skyline of Belfast and to the architecture of what is now becoming known as the Legal Quarter. The building, which has already received several awards, provides a working environment which fulfils the needs of a growing and modern Bar.

Thanks were also paid to Donnell Deeny and the Art Committee for the choice of works of art including two special commissions, i.e. a piece in the foyer entitled "The History of the Wig" by John Kindness and the bronze reliefs on the main doors depicting various images of law and justice which are the work of Carolyn Mulholland. The current issue of "Perspective", the magazine of the Royal Society of Ulster Architects, states:

"This is an important building for Belfast. The Library's tone of openness establishes an optimistic and encouraging face for our legal justice system."

This is exactly the kind of image which members of the Bar wished to achieve. The building gives them a working environment with research and back-up facilities unmatched by anyone offering advocacy services in these Islands. The Northern Ireland Bar is a modern Bar ready to meet whatever challenge lies ahead and this building enables the Bar to offer the type of service now expected by its clients.

Peter Cush then invited the Nobel Laureate, Seamus Heaney, to address the guests and Professor Luzius Wildhaber, President of the European Court of Human Rights to perform the unveiling of the commemorative stone.

\section{Seamus Heaney: Poet and Nobel Laureate}

The first lawbook written in the west, the only lawbook with which I am in any way familiar, is the third party of Aeschylus's trilogy, The Orestia. The final play in that great group was performed in Athens in the fifth century $\mathrm{BC}$ and is generally known as The Eumenides. 
But the play could equally well be known as The Court of Athens or The Athens Truth and Reconciliation Commission, because the story it tells is of the end of a world where the Furies were the dominant force and of the beginning of a new world where authority would henceforth be vested in a system of law. The Furies embodied the spirit of retribution, the need to have crime avenged, and, in particular, crimes of blood - avenged, if necessary, by the spilling of more blood. But the play shows how this ancient blood-forblood ethic gives way to the word of the goddess Athena, goddess of wisdom, goddess of Athens, patron of the first court of twelve citizens, patron of a system of civil and administrative justice which she institutes and authorizes. The Furies become the Kindly Ones, the Eumenides of the title. They submit to what Athena calls Holy Persuasion and are welcomed into ground beneath the city, acknowledged as fundamental realities, their dark provenance the other side of the bright Athenian coin.

I bring all this up because at the opening of this magnificent new law library, it seems appropriate to remember how fundamental to civilized life is our agreed respect for the workings of the law and the courts, and how fragile. And indeed the people of Northern Ireland have a veteran awareness of these matters, a deeper than average experience of both the impulse towards furious retribution and the need for a reconciliation that is both tough minded and civilized. But I also bring up the memory of Athens and the matter of the law because the mighty doors to this building are now adorned with an image of the heroine of another great Greek tragedy - the image, that is, of Antigone, and Antigone, let us not forget, experienced what many on both sides of this society have also experienced: a deep conflict between the things decreed by government and the things decreed by their own deepest pieties and principles.

It so happened that when Carolyn Mulholland was starting on her commission to furnish these beautiful, burnished, biblio-epic doors, in consultation with the chairman of your Art Committee, Donnell Deeny, I was starting on a commission to translate Antigone for the Abbey Theatre's centenary in 2004. We both recognized that these were parallel projects with the result that I ended up almost as excited about Carolyn's work as she was. I know, ladies and gentlemen, that we are here to celebrate several other artists whose work adorns this place and many of them are friends of mine, but I hope they will forgive me for making special mention of the doors, because Carolyn has been a close friend of ours now for almost forty years. We kept on at any rate, free-associating about various law legends and law locations, about Brehons in Ireland and Vikings at the althing, about the tables of the law and the temples of the gods, about Portia, about the polis, and about images associated with all these things - those images, as Yeats calls them, "that yet Fresh images beget." Carolyn moreover, is doubly gifted as an artist since she believes in words as well as images, and it is one of the glories of these doors that she has been able to incorporate oracular words from so many different places and periods. Words like the original Irish copyright law, "To every cow its calf, to every book its copy" or the gnomic Icelandic maxim; "With law our land be built or with lawlessness laid waste" or the tragic recognition of the Chorus in Antigone: "Wise conduct is the key to happiness. Always rule by the gods and reverence them."

The words "law" and "library" are hallowed words. So is the word "art". They belong in that cluster of the humanist vocabulary that has to be made 
credible and operative over and over again by jurists and artists and architects and all men and women of good will, all those who would do what Yeats, in another noble phrase, once called "the spiritual intellect's great work". The pictures on these walls remind us that the artists who have lived through dangerous times are not necessarily changed utterly, that they don't necessarily bring forth terrible beauty but rather counter the times with true and vivid forms; true temperaments as different as those of John Kindness, Felim Egan, Graham Gingles, Clement McAleer, Simon McWilliams, Jack Packenham, Martin Wedge and Paddy McCann. The images on the doors are memorable, bold and archetypal. The grand design that Carolyn has executed will stand for what it is, bronze cast in commanding forms to engross the eye and the mind. But it will stand also as a reminder of the absolute value and necessity of that ongoing work of spirit and intellect, of its power and indeed its glory.

\section{Professor Luzius Wildhaber: President of the European Court of Human Rights}

It is a great honour and privilege for me to be asked to take part in the opening ceremony of this wonderful new Bar Council Library Building. I am sure that all those who will spend their professional lives working here will find themselves inspired - as I have been - by the sense of light and openness to the community which graces this building. As we have discovered with our own relatively new building in Strasbourg, architecture can be a source of inspiration for busy professionals, though not always a source that is recognised with a unanimous voice. Building for lawyers is, I would venture to say, necessarily a contentious exercise. However, the opening of a building is always a fitting moment to reflect on the wider picture. Allow me to do so with reference to our common pursuit; the protection of human rights through the legal process.

One insight comes to mind on this occasion. James Madison - one of the founding fathers of the Constitution of the United States - has spoken eloquently of liberty and learning each "leaning on the other for their mutual and surest support". Working as a President of a chronically busy international tribunal which examines human rights complaints from 44 jurisdictions, I am struck by the aptness of this observation. There is an obvious inter-dependence between learning and the protection of human rights and maintenance of the rule of law. We rely on the knowledge and skills of advocates to assert and plead human rights issues before the national courts as an essential part of the process that leads to judicial recognition and enforcement of rights by the national courts. Learning equally informs the reasoned decision of the judges. We also rely on these skills when a case is pleaded before the Court in Strasbourg and I can assure you that the adjudicatory task is made easier - indeed greatly assisted - when the matter is artfully pleaded in a manner which encompasses the essence of the argument with the sharpness and clarity that we have come to expect from lawyers trained in the common law system.

But there is also a wider sense in which the observation is true which relates directly to the work of the European Court of Human Rights. 
The Convention system is essentially a system of last resort which should only come into play when redress for the complaint has been first been sought before the local courts. In this sense it is often described as a system which is subsidiary to that of the national system - a system of outer protection, if you prefer. The underlying philosophy of the Convention system is that human rights should first be protected at home and that the national courts should be afforded the opportunity to apply the provisions of the Convention to the issues at hand, preferably (but not as a matter of obligation) against the background of Strasbourg case-law. It is only if this is not possible or if there is discord between the rules applied locally and Strasbourg jurisprudence, that the Court would step in. I would add, in parenthesis, that given the large number of cases brought every year to Strasbourg, the future of the system now depends on the effective protection of human rights at national level.

Of course, the Convention system works best in States where incorporation has taken place. I am well aware that there was a time when judges in Northern Ireland or in other parts of the United Kingdom were not receptive to Convention points being raised before them. There existed what could politely be called a "constitutional resistance" to national courts applying Convention standards or indeed even interpreting administrative law principles against the background of the Convention. But that belongs to the past. Convention law is now an integral part of your legal system and lawyers can now plead Strasbourg jurisprudence directly before the domestic courts. This in turn makes it easier for the Court in Strasbourg to adjudicate when it is confronted with a fully reasoned national judgment where the courts have sought to establish the relevant Strasbourg law and to apply it to the case under consideration. It also means that the national courts are in a position to contribute to the development of human rights law throughout Europe to the extent to which their judgments inform and influence the development of Strasbourg law by the European Court. The judgments of the United Kingdom courts in Pretty, Goodwin, Stafford and Amin are excellent examples of this. The poet's observation that "the law makes long spokes out of the short stakes of man" has never been truer.

This respectful exchange and dialogue with national courts on a continuous basis through the medium of decided cases not only aids the adjudicatory process but enlivens and enriches the quality of the Strasbourg Court's case law. It is based on a notion of partnership in the common task of ensuring the protection of the Convention's guarantees, a partnership which has become a practical necessity in a Convention community involving 44 Contracting States with a combined population of some 800 million Europeans.

Of course it depends heavily for its success on an active and informed legal profession as well as on the judges. It falls to lawyers to identify appropriate cases in which to raise a Convention issue and also to keep abreast of jurisprudential developments. As those of you who have been involved in human rights cases will know, this may be no easy task for it calls on a breadth of vision which goes beyond the provincial or indeed the national. It is not uncommon for the Court to be confronted, in important cases, with citations from the superior courts in the USA, Canada, South Africa, and now the House of Lords. Modern means of technology have promoted this development which, in my view, can only be beneficial since it taps into the 
wisdom of other experiences and other jurisdictions. Exposure to alternative ways of analysing constitutional issues can only be seen as a healthy challenge to traditional habits of thought. The recent decision of the United States Supreme Court in Lawrence v Texas offers a recent example. The willingness of the Strasbourg Court to refer to decisions of both the US Supreme Court and the Inter-American Court of Human Rights is a further example. In this sense also, liberty and learning rely on each other for mutual sustenance.

Let me just add one final note on incorporation which places the emphasis more on practical experience than either liberty or learning. As lawyers from a jurisdiction which has given rise to some of the Court's leading cases, you will all be too well aware of how incorporation actually works in practice. I can only hope that you do not recognise yourselves too closely in the following advice given by a senior British counsel to his pupil. The counsel said: if you have the law on your side, you should argue the law. If you have the facts on your side, you should argue the facts. But, said the pupil, who obviously had a bright future, what if you have neither the law nor the facts on your side? Well then, came the reply, just tell the judge it's a human rights issue.

It is clear to me on the joyous occasion of the opening of this building - and judging from your response - that incorporation of the Convention into Northern Irish law has a great future ahead of it. 